\title{
KOLABORASI TEORI KEADILAN JOHN RAWLS DAN DIAKONIA TRANSFORMATIF JOSEF PURNAMA WIDYATMADJA UNTUK KOMUNITAS YANG MEMPERJUANGKAN KEADILAN
}

\author{
Hudiman Waruwu ${ }^{1}$, Minggus Minarto Pranoto ${ }^{2}$ \\ Gereja Isa Almasih Weleri ${ }^{1}$, Sekolah Tinggi Theologia Abdiel ${ }^{2}$ \\ hudimanwaruwu@gmail.com ${ }^{1}$,minggusminarto@gmail.com ${ }^{2}$
}

\begin{abstract}
Abstrak
Berbicara tentang keadilan maka hal ini merupakan kebajikan dalam hidup masyarakat. Setiap orang ingin menjalani hidup ini dalam keadilan. Namun, harapan akan keadilan sampai saat ini masih diperjuangkan. Berbagai hal, cara atau usaha dilakukan untuk memperjuangkan keadilan. Maka dari itu, sebagai alternatif dalam memperjuangkan keadilan, penulis mengkolaborasikan teori keadilan John Rawls dan diakonia transformatif Josef komunitas dalam memperjuangkan keadilan. Kedua tokoh ini sama-sama memiliki keprihatinan terhadap ketidakadilan. Rawls mengatakan bahwa untuk memperjuangkan keadilan harus melalui kesepakatan bersama yang dihasilkan dalam posisi asali, dan Josef mengatakan dengan diakonia trasformatif, keadilan dapat ditegakkan dan diperjuangkan. Untuk mencapai ini, rakyat harus menjadi subyek dan membentuk komunitas, dari komunitas tersebut masalahmasalah sosial dipecahkan dan diusahakan solusi sampai menghasilkan kesepakatankesepakatan yang terorganisir dengan berdasar pada prinsip keadilan. Di dalam komunitas, tidak ada SARA, semua golongan dan kalangan sama dan setara. Berpegang teguh pada nirkekerasan, dan mengedepankan solidaritas-partisipatoris demi keadilan.
\end{abstract}

Kata kunci: keadilan; kebebasan; komunitas; spritualitas; nir-kekerasan

\begin{abstract}
Speaking of justice, this is a virtue in society's life. Everyone wants to live in justice. However, hopes for justice are still being fought for. Various things, the ways or efforts are made to fight for justice. Therefore, as an alternative to fighting for justice, the authors collaborate with John Rawls's theory of justice and Josef's transformative diaconia community in fighting for justice. Both of these figures have concerned about injustice. Rawls said that to fight for justice must be through a collective agreement produced in the original position, and Josef said that with the formalized diaconia, justice could be upheld and championed. To achieve this, the people must be the subject and form a community; and from such a community, social problems are solved and endeavored solutions to produce organized agreements based on the principle of justice. In the community, there is no SARA, all groups and circles are equal, hold fast to nonviolence, and to promote participatory solidarity for the sake of justice.
\end{abstract}

Keywords: justice; freedom; community; spirituality; nonviolence

\section{Pendahuluan}

Berbicara tentang keadilan tidak ada habisnya dan sampai saat ini masih diperjuangkan. Harapan untuk keadilan begitu besar. Sebagaimana sila kelima Pancasila berbunyi "keadilan sosial bagi seluruh rakyat Indonesia." Sila kelima ini merupakan harapan masyarakat Indonesia, agar keadilan benar-benar terwujud dalam kehidupan 
masyarakat. Semuanya ingin hidup dalam keadilan, hak, dan kewajiban setiap pribadi dan orang banyak.

Patut dipertanyakan darimana mulainya menegakkan keadilan? Siapa yang menegakkan keadilan? Harus bagaimana menegakkan keadilan? Bila ditelusuri, sampai saat ini upaya-upaya yang dilakukan untuk menegakkan keadilan belum menemukan titik penyelesaian. Masih ada ketimpangan. Begitu banyak masalah ketidakadilan terjadi dalam kehidupan masyarakat. Di manakah keadilan?

Pertanyaan di atas seharusnya menggugat manusia itu sendiri, karena hanya manusialah yang dapat menegakkan keadilan. Untuk itu, dibutuhkan sebuah konsep dan prinsip-prinsip keadilan yang memiliki prioritas dalam membangun sebuah ideologi yang berkeadilan. Oleh karena itu-melalui teori keadilan John Rawls dan diakonia transformatif Josef Purnama Widyatmadja - penulis akan menjabarkannya untuk menjadi suatu alternatif dalam menegakkan keadilan. Penulis akan mengkolaborasikan tentang pemikiran Rawls dan Josef dalam penegakan keadilan terhadap kebebasan berkeyakinan, ekonomi yang berkeadilan, dan pemahaman nir-kekerasan. Dengan tujuan agar dapat menjadi panduan dan alternatif untuk komunitas sosial dalam memerjuangkan keadilan.

\section{John Rawls dan Teori Keadilan}

Rawls adalah seorang tokoh ternama di abad-20 melalui karya agungnya tentang teori keadilan. Rawls lahir di Baltimore Maryland pada tahun 1921. Nama lengkapnya adalah John Borden Rawls. Rawls mengawali karier dengan belajar konsep religius. Di tahun 1939, Ia masuk Universitas Princeton. Di Princeton Rawls mendalami filsafat melalui seorang guru yang bernama Norman Malcolm (salah seorang sahabat dan pengikut Wittgenstein). Selesainya di Princeton, ia melanjutkan berkarier melalui masuk militer dan pernah diutus bertugas di Pasifik, New Guinea, Filipina dan Jepang ${ }^{1}$. Pendidikan doktoral diselesaikan di Princeton, dengan menggeluti dan menulis tentang Filsafat Moral pada tahun 1949-1950. Dari studi yang digelutinya, Rawls terus mengembangkan Teori Keadilan. Risalah yang dikembangkannya tentang teori keadilan, menghabiskan waktu selama 20 tahun. Konsep "the original position" ditulisnya saat mengajar di Oxford dan konsep ini baru sempurna saat ia memperbaiki gagasannya tentang "the veil of ignorance". Di tahun 1957, Rawls kembali menuangkan ide pikirannya tentang konsep keadilan dengan judul artikel "Justice as Fairness" yang merupakan inti dari teori keadilannya dan di tahun

${ }^{1}$ Andre Ata Ujan, Keadilan Dan Demokrasi: Telaah Filsafat Politik John Rawls (Yogyakarta: Kanisius, 2005), 14-15. 
1960 konsep tentang A Theory of Justice diseminarkannya dihadapan publik dan akademisi. Di tahun 1962, ia bergabung di Unversitas Harvard sebagai Guru Besar². Di tahun 1971, teori keadilan Rawls dibukukan.

\section{Keadilan Sebagai Fairness}

Dalam karya dan karier Rawls, tercipta teori keadilan yang disebut keadilan fairness dengan tujuan mengupayakan teori keadilan yang dapat menjadi alternatif untuk menegakkan keadilan, dan sekaligus mengungguli paham utilitarian dan intuisionisme dari semua versi pemikiran alternatifnya ${ }^{3}$. Rawls menciptakan alternatif untuk menegakkan keadilan yang dinamakan keadilan sebagai fairness.

Rawls, membangun teori keadilan sebagai fairness berdasar pada teori kontrak sosial yang menghasilkan prinsip-prinsip keadilan bagi struktur dasar masyarakat melalui kesepakatan ${ }^{4}$. Keadilan sebagai fairness menghasilkan prinsip-prinsip keadilan dan kesepakatan yang menentukan hak dan kewajiban serta pembagian keuntungan sosial yang ditentukan dalam keberadaan sebagai posisi asali ${ }^{5}$.

Masyarakat yang adil dalam keadilan sebagai fairness berbicara adanya kebebasan dan kesetaraan dalam struktur dasar masyarakat. Hak dan kewajiban diperhatikan dengan adil. Hak dan kewajiban yang fundamental menjadi prioritas dalam struktur dasar masyarakat dan dasar dalam membangun prinsip-prinsip keadilan serta menentukan pembagian keuntungan dan beban kerjasama sosial secara adil.

\section{Posisi Asali}

Untuk mencapai konsep keadilan sebagai fairness harus melalui keberadaan yang disebut posisi asali. Posisi asali ini dipahami sebagai situasi hipotesis yang dicirikan mengarah pada konsepsi keadilan ${ }^{6}$. Posisi asali dalam keadilan sebagai fairness adalah orang-orang yang ditempatkan mengambil kesepakatan dan mempertimbangkan prinsipprinsip yang berkeadilan. Orang-orang tersebut menyusun kesepakatan dari prinsip-prinsip keadilan dan menjamin berlangsungnya prinsip-prinsip keadilan. Posisi asali tersebut merupakan representasi dari orang-orang yang rasional, bebas, dan menaruh minat dalam

\footnotetext{
${ }^{2}$ Ibid.

${ }^{3}$ John Rawls, Teori Keadilan: Dasar-Dasar Filsafat Politik Untuk Mewujudkan Kesejahteraan Sosial Dalam Negara (Yogyakarta: Pustaka Pelajar, 2006), 25.

${ }^{4}$ Ibid., 12.

${ }^{5}$ Ibid., 13 .

${ }^{6}$ Ibid., 13.
} 
penegakan keadilan serta menerima prinsip kesamaan dalam menciptakan masyarakat $\operatorname{adil}^{7}$. Keberadaan dalam posisi asali, hak dan kewajiban yang fundamental harus menjadi dasar dalam memahami prinsip-prinsip keadilan yang diputuskan secara kesepakatan dengan fair. Selain itu, dalam posisi asali diposisikan sebagai veil of ignorance (tabir ketidaktahuan $)^{8}$. Dari titik tolak ini, pihak-pihak yang terikat dalam kontrak atau posisi asali ${ }^{9}$, memiliki tugas utama dalam menyusun konsep keadilan sebagai fairness yaitu menentukan prinsip keadilan mana yang akan dipilih dalam posisi asali ${ }^{10}$. Maka, sebagaimana dengan pandangan-pandangan kontrak lainnya, keadilan sebagai fairness terdiri dari dua bagian: pertama interpretasi atas situasi awal atas persoalan pilihan yang ada; kedua, seperangkat prinsip yang akan disepakati ${ }^{11}$.

Tentang konsep hak dalam keadilan sebagai fairness lebih diutamakan dari pada konsep tentang manfaat. Hak merupakan prioritas dan kriteria pada desain struktur dasar secara keseluruhan dan tidak diperbolehkan melahirkan kecenderungan dan sikap yang bertentangan dengan dua prinsip keadilan. Kewajiban didefenisikan dalam pengertian kebutuhan.

Seseorang diwajibkan melakukan perannya sebagaimana yang ditentukan oleh aturan lembaga atau struktur dasar ketika dua kondisi dipenuhi. Pertama, lembaga adil yakni memenuhi kedua prinsip keadilan. Kedua, orang secara sukarela menerima keuntungan dari tatanan atau mendapat keuntungan dari peluang yang ditawarkannya demi

\footnotetext{
${ }^{7}$ Bur Rasuanto, Keadilan Sosial: Pandangan Deontologis Rawls Dan Habermas, Dua Teori Filsafat Politik Modern (Jakarta: Gramedia, 2005), 53.

${ }^{8}$ Ibid., 53. Yang dimaksud dengan veil of ignorance (tabir ketidaktahuan) yaitu tidak tahu jenis fakta khusus. Tidak ada yang tahu tempatnya di dalam masyarakat, posisi kelas atau status sosialnya; tidak tahu keberuntungannya dalam distribusi aset-aset serta kecakapan alamiah, kecerdasan dan kekuatannya; tidak tahu soal konsepsinya tentang manfaat, hal-hal dari rencana hidup rasionalnya bahkan psikologinya seperti kebencian pada resiko atau liabilitasnya pada optimisme dan pesimisme. Posisi asali diasumsikan tidak tahu situasi khusus dari masyarakat mereka sendiri. Yakni mereka tidak tahu situasi ekonomi dan politik mereka. Tidak tahu tingkat peradaban dan kebudayaan mereka yang sudah dicapai. Dalam hal ini, fakta-fakta khusus yang diketahui mereka adalah masyarakat mereka tunduk pada situasi keadilan dan apapun yang mereka implikasikan. Mereka adalah yang tahu fakta-fakta umum tentang masyarakat manusia. Memahami urusan politik dan prinsip-prinsip teori ekonomi. Mereka tahu basis bagi organisasi sosial serta hukum-hukum psikologi manusia. Mereka dianggap tahu fakta-fakta umum apapun yang mempengaruhi pilihan akan konsep keadilan. Sebab, konsep keadilan disesuaikan dengan karakteristik sistem kerjasama sosial yang mereka atur. Dengan keberadaan seperti ini, pihak-pihak dalam posisi asali dalam mengambil kesepakatan harus berpijak dari prinsip yang menegaskan kebebasan yang merata bagi semua, termasuk perataan kesepakatan, dan distribusi yang adil atas pendapatan dan kesejahteraan, terkecuali apabila kesenjangan atau ketidakadilan bisa dikatakan adil, jika dan hanya jika menguntungkan orang-orang yang kurang beruntung.

${ }^{9}$ Ibid., 18 \& 19. Pemahaman terhadap kontrak disini lebih menuju kepada kandungan kesepakatan bukanlah untuk memasuki masyarakat yang ada atau menggunakan bentuk pemerintahan yang ada, namun untuk menerima prinsip-prinsip moral tertentu (Ibid,18). Dan gagasan kontrak dapat diperluas hingga pilihan seluruh sistem etis, yakni: hingga sebuah sistem yang meliputi prinsip-prinsip semua kebajikan dan tidak hanya keadilan. Dari rumusan ini perlu dipertegas bahwa keadilan sebagai fairness bukan merupakan teori kontrak yang lengkap (Ibid, 19).

${ }^{10}$ Ibid., 15.

${ }^{11}$ Ibid., 17.
} 
mengejar kepentingannya. Gagasannya adalah ketika sejumlah orang terlibat dalam kerjasama yang saling menguntungkan sesuai dengan aturan, lantas membatasi kebebasan mereka agar memberikan keuntungan untuk semua orang, mereka yang patuh pada batasan tersebut punya hak mendapat kepatuhan serupa dari orang-orang yang mendapat keuntungan dari ketundukan mereka ${ }^{12}$. Dengan kata lain, kewajiban kita lakukan demi kebutuhan bersama dan keuntungan bersama sesuai dengan kedua prinsip keadilan.

Untuk mencapai keadilan yang fair, Rawls merumuskan dua prinsip keadilan yang menjadi panduan dan landasan prinsip dalam keadilan sebagai fairness. Dua prinsip keadilan yang fair ini, Rawls yakini membawa keadilan di tengah-tengah ketidakadilan yang terjadi. Dua prinsip tersebut adalah

Pertama, setiap orang mempunyai hak yang sama atas kebebasan dasar yang paling luas, seluas kebebasan yang sama bagi semua orang. Kedua, ketimpangan sosial dan ekonomi mesti diatur sedemikian rupa sehingga: (a) dapat diharapkan memberi keuntungan semua orang; (b) semua posisi dan jabatan terbuka bagi semua orang ${ }^{13}$.

Kedua prinsip ini menyatakan bahwa semua orang mendapat keuntungan dari ketimpangan sosial dan ekonomi. Prinsip-prinsip ini mengatur hak dan kewajiban dan mengatur distribusi keuntungan sosial dan ekonomi. Kebebasan dasar yang dimaksud pada prinsip pertama melingkupi kebebasan politik (hak untuk memilih dan dipilih menduduki jabatan publik) bersamaan dengan kebebasan berbicara dan berserikat; kebebasan berkeyakinan dan kebebasan berpikir; kebebasan seseorang seiring dengan kebebasan untuk mempertahankan hak milik (personal); dan kebebasan dari penangkapan sewenangwenang sebagaimana didefinisikan oleh konsep rule of law. Kebebasan-kebebasan ini diharuskan setara, karena suatu masyarakat yang adil mempunyai hak-hak dasar yang sama $^{14}$. Prinsip kedua, berbicara tentang pendistribusian pendapatan dan kekayaan serta desain organisasi yang menggunakan perbedaan dalam otoritas dan tanggungjawab yang tidak perlu sama. Tetapi, harus didasarkan atau demi keuntungan semua orang, khususnya bagi yang tidak beruntung ${ }^{15}$. Prinsip kedua terdiri dari dua frase: pertama, diharapkan memberi keuntungan semua orang; kedua, semua posisi dan jabatan terbuka bagi semua orang. Pengertian prinsip kedua ini mengatakan bahwa di bawah kesamaan kesempatan yang fair, ketidaksamaan pendistributian diizinkan apabila menguntungkan semua orang

\footnotetext{
${ }^{12}$ Ibid., 134.

${ }^{13}$ Ibid., 72.

${ }^{14}$ Ibid., 73.

${ }^{15}$ Ibid., 75.
} 
khususnya golongan yang paling tertinggal. Yang dimaksud dengan "paling tertinggal" pada 2a adalah secara ekonomi dan sosial; yang dimaksud "takkesamaan" pada $2 \mathrm{~b}$ adalah perbedaan dalam nikmat dan beban. Perbedaan antara jabatan-jabatan dan pangkat yang disebut dalam $2 \mathrm{~b}$, adalah perbedaan nikmat dan kewajiban yang melekat langsung maupun tidak langsung pada pangkat atau jabatan itu. Dalam frase kedua menekankan pada kesempatan bagi setiap orang untuk terbuka mencalonkan diri dan dapat memiliki kesempatan kesamaan dalam memperebutkan posisi jabatan. Bukan karena faktor jabatan atau kedudukan, melainkan karena kesetaraan dalam nilai-nilai sosial dan ekonomi.

Dengan adanya prinsip ini dalam posisi asali, Rawls yakin bahwa apa yang dicitacitakan tentang keadilan dalam masyarakat fair. Sebaliknya jika prinsip ini tidak diakui dan diterima dalam masyarakat maka terjadi kegagalan. Dari itu, dibutuhkan penghargaan yang saling menghargai dan menghormati ${ }^{16}$ atas apa yang sudah disepakati dalam prinsipprinsip yang telah diputuskan oleh pihak-pihak di posisi asali.

\section{Diakonia Transformatif Josef Purnama Widyatmadja}

Josef Purnama Widyatmadja lahir di Kudus pada 7 Desember 1944. Josef menempuh pendidikan SMP di Sekolah Tionghoa (Koe Hwa), Kudus. SMA di semarang, yang dikenal SMA In Hwa di jalan Gajah Mada Semarang ${ }^{17}$. Melanjutkan studi di STT Duta Wacana, lulus tahun 1971, dan pada tahun1972 mengikuti pelatihan urban industrial mission $^{18}$. Pokok pembahasan dalam pelatihan ini adalah bagaimana cara mengorganisasi rakyat miskin dalam memperjuangkan keadilan dan hak-hak mereka sebagai manusia. Mulai dari pelatihan ini, Josef belajar tentang cara memberdayakan masyarakat di bawah bimbingan David L. Zurvernik, seorang misionaris Presbyterian Church Amerika dan Karel Danuriko, seorang lulusan Sekolah pastor Katolik yang sudah dilatih di Tondo, Manila. Setelah Josef menyelesaikan pelatihan, ia menggumulkan bagaimana menerapkan ilmu yang didapat dari pelatihan tentang community organization, di gereja maupun di kalangan masyarakat. Dari itu Josef membingkai kegiatan community organization melalui kegiatan diakonia transformatif, yang bertujuan membebaskan dan memberdayakan orang miskin. Diakonia transformatif ini diperlukan pada saat keadilan diabaikan. Metode dari

\footnotetext{
${ }^{16}$ Ibid., 216-218.

${ }^{17}$ Ibid., 15.

${ }^{18}$ Ibid., 23.
} 
diakonia ini adalah membuka mata orang buta dari kebutaan atas hak-haknya serta bangkit dari kondisi ketidakadilan ${ }^{19}$.

Kerajaan Allah dan Rakyat

Josef mengembangkan pemahaman tentang diakonia transformatif berawal dari konsep Kerajaan Allah. Dalam Alkitab, konsep tentang Kerajaan Allah menjadi pemberitaan sentral. Pelayanan Yesus, bertitik tolak dari konsepnya tentang Kerajaan Allah. Kerajaan Allah yang disampaikan Yesus bukan hanya sekadar perwartaan agama, tetapi juga suatu proklamasi yang menyentuh segala aspek kehidupan. Para nabi di Perjanjian Lama telah memberitakan kedatangan Kerajaan Allah. Misalnya nabi Yesaya telah menubuatkan tentang kedatangan kerajaan Allah. Di Perjanjian Lama tercatat bagaimana sikap terhadap memperhatikan orang miskin, melalui kedatangan tahun Yobel (Imamat 25). Tahun Yobel merupakan bagian ketentuan Allah untuk menciptakan manusia baru dan bumi baru di mana penderitaan dan kelaparan umat diakhiri. Kehadiran Yesus di dunia dinyatakan sebagai kedatangan Kerajaan Allah sedang berlangsung untuk diwujudnyatakan. Dalam Injil, Yesus menyampaikan kabar baik dengan pelayanan kasih yang dilaksanakan dalam tindakan mesianik. Pelayanan Yesus sangat berbeda dengan pemerintahan dunia serta kerajaan Israel secara politis. Bahkan Kerajaan Allah berhadapan dengan kerajaan dunia, dan ditentang oleh kerajaan dunia dan agama ${ }^{20}$.

Kerajaan Allah, berbicara tentang mewujudnyatakan manusia dan dunia baru yang ditampakkan dengan perdamaian, keadilan, kesejahteraan rakyat, dan keutuhan ciptaan. Kerajaan Allah ada dan hadir di antara manusia, di antara rakyat, di tengah-tengah orang miskin yang tertindas dan putus asa. Yesus menyuarakan bahwa Kerajaan Allah datang atas mereka yang miskin, lemah dan tertindas ${ }^{21}$. Yesus menyampaikan apa tujuan dan misiNya di dunia, Ia mengatakan "Roh Tuhan ada pada-Ku, oleh sebab Ia telah mengurapi Aku, untuk menyampaikan kabar baik kepada orang-orang miskin; dan Ia telah mengutus Aku untuk memberitakan pembebasan kepada orang-orang tawanan, dan penglihatan bagi orang-orang buta, untuk membebaskan orang-orang yang tertindas, untuk memberitakan tahun rahmat Tuhan telah datang (Lukas 4:18-19)." Seluruh ajaran, tindakan, dan sikap

\footnotetext{
${ }^{19}$ Ibid., 27.

${ }^{20}$ Josef P Widyatmadja, Yesus Dan Wong Cilik: Praksis Diakonia Transformatif Dan Teologi Rakyat Di Indonesia (Jakarta: BPK Gunung Mulia, 2010), 13.

${ }^{21}$ Ibid., 15.
} 
Yesus selalu mengarah pada konsep hadirnya Kerajaan Allah. Dengan kata lain, bahwa misi Yesus adalah mewujudkan Kerajaan Allah.

Kerajaan Allah tidak dihubungkan dengan golongan masyarakat yang menindas. Yesus mewartakan Kerajaan Allah ditujukan kepada orang miskin dan bagi orang kaya yang bertobat. Dalam Lukas 4:18-20, Yesus mengatakan bahwa Ia membawa kabar baik bagi orang miskin, pembebasan orang tertawan, penglihatan bagi orang buta, pelepasan orang tertindas. Dalam hal ini orang kaya tidak ditolak dalam Kerajaan Allah. Kerajaan Allah terbuka bagi orang kaya, jika bertobat, dan mau lahir baru, seperti Zakheus, Nikodemus, dan Lewi. Orang kaya dipanggil untuk memberikan dan melakukan perhatian kepada orang miskin. Sebagaimana yang dicatat dalam Matius 25:40 "segala sesuatu yang kamu lakukan untuk salah seorang dari saudara-Ku yang paling hina ini, kamu telah melakukannya untuk $\mathrm{Aku}^{22}$. Gerakan mesianik Yesus tidak sama dengan perjuangan gerakan kemerdekaan nasionalisme Israel. Bahkan Yesus mengatakan Kerajaan Allah berbeda dengan membangun kembali kerajaan Daud (Kisah Para Rasul 1) ${ }^{23}$.

Inkarnasional yang Membebaskan

Melalui inkarnasi, Allah menyatukan diri dengan penderitaan manusia. Allah mengambil tindakan inkarnasi sebagai wujud solidaritasNya dengan mereka yang miskin, lemah, dan tertindas secara ekonomi dan politik. Allah tidak hanya mendengar dan melihat penderitaan manusia dari atas surga. Allah adalah Allah yang mau turun di tengah-tengah penderitaan manusia. Ia tidak sekadar melakukan incognito, tetapi ber-inkarnasi. Allah turun ke sungai Nil bukan untuk menjaga status quo atau keseimbangan yang semu, tetapi akan mengadakan perubahan mendasar. Membebaskan dan memerdekakan umat Israel dari penindasan yang dilakukan oleh Firaun. Allah datang dalam diri Yesus bukan untuk mengawetkan status quo. Tetapi, inkarnasi adalah suatu manifestasi kasih Allah yang membebaskan mereka yang miskin dan lemah di dalam masyarakat dari kuasa dosa struktural $^{24}$.

Inkarnasi Allah dalam pribadi Yesus, menggerogoti struktur sosial ekonomi dan politik serta struktur agama Yahudi dengan gerakan sosial dan politik nir-kekerasan. Menanggung cemoohan, dituduh subversif, dan dengan penuh kesadaran menanggung

${ }^{22}$ Ibid., 16.

${ }^{23}$ Ibid., 17.

24 Julianus Mojau, Meniadakan Atau Merangkul? Pergulatan Teologis Protestan Dengan Islam Politik Di Indonesia (Jakarta: BPK Gunung Mulia, 2012), 160. 
penaganiayaan atas diriNya sebagai tanda solidaritasNya yang sejati dengan mereka yang dibelaNya. Yesus justru mewujudkan misi pembebasan Allah dengan merelakan diriNya untuk disalibkan $^{25}$. Dari uraian ini, pelayanan Yesus menjadi dasar bagi murid untuk membangun spiritualitas yang membebaskan dan memberdayakan mereka yang miskin, lemah, dan tertindas ${ }^{26}$.

\section{Teologi Rumput}

Dalam refleksi dan praksis iman, Josef menciptakan sebuah teologi yang diberi nama teologi rumput. Disebut sebagai teologi rumput, karena rumput sebagai simbol kekuatan rakyat yang sering dianggap lemah ${ }^{27}$. Dalam teologi rumput ini, konteks berteologi harus berlandaskan pada analisis sosial masyarakat di tempat kita berada. Budaya setempat harus diperhatikan dan dikembangkan dalam teologi rumput. Alkitab menjadi sumber inspirasi iman dengan berbasis pada keterlibatan orang beriman sebagai pengikut Yesus di tengah masyarakat. Menyusun atau membangun teologi bersama mereka yang miskin dan tertindas. Teologi rumput menumbuhkan spiritualitas perjuangan rakyat, menjadi jawaban atas ketidakadilan dan menjunjung perdamaian antara suku, ras, budaya, dan agama ${ }^{28}$.

Teologi rakyat lahir dari interaksi antara refleksi kritis dan praksis. Peristiwa Keluaran adalah peristiwa pembebasan di mana menjadi landasan teologi Israel. Peristiwa salib dan kebangkitan menjadi landasan teologi pengikut Yesus. Teologi rakyat adalah teologi yang berpihak pada miskin dan tertindas. Ia bersumber pada budaya lokal. Teologi rakyat menjadi reaksi atas filsafat dan ideologi yang menindas mereka, tidak sistematis tetapi reflektif terhadap persoalan hidup dalam terang Alkitab. Teologi rakyat menghadirkan nilai kebenaran etis, nilai keadilan sosial dan pembebasan yang utuh. Rakyat menjadi subjek atau pelaku, analisis sosial memihak pada rakyat, menghormati dan mengembangkan budaya rakyat, mengukuhkan perjuangan rakyat. Keberadaan fasilitator dalam teologi rakyat sangat penting untuk mendampingi dan mengarahkan ${ }^{29}$.

\footnotetext{
${ }^{25}$ Ibid., 163.

${ }^{26}$ Widyatmadja, Yesus Dan Wong Cilik: Praksis Diakonia Transformatif Dan Teologi Rakyat Di Indonesia, 92.

${ }^{27}$ Ibid., 103.

${ }^{28}$ Ibid., 104.

${ }^{29}$ Ibid., 102.
} 
Josef mengatakan dalam teologi rumput perlu cara baru atau paradigma baru dalam rangka mengembangakan teologi rumput ${ }^{30}$, antara lain adalah: seorang aktivis atau fasilitator perlu memiliki cara baru melihat realitas. Realitas yang ada di dunia ini, bisa diubah menjadi lebih baik. Melihat realitas dengan bermimpi dan berjuang untuk mengubah realitas. Impian yang ada direalisasikan menjadi impian semua orang dan menjadi sumber pengharapan masa depan yang bisa menjadi kenyataan. Selanjutnya, memiliki cara baru membaca Alkitab. Membaca Alkitab harus dimulai dengan konteks tempat kita berada. Menafsirkan kehidupan dengan pertolongan terang Alkitab. Umat dan aktivis diakonia transformatif menafsirkan kehidupan sehari-hari dan pelayanannya dengan dan di dalam terang Alkitab. Dengan cara baru membaca Alkitab menjadikan Firman Tuhan menyatu dengan kehidupan sehari-hari dan menjadi sumber kekuatan dan hidup bagi aktivis diakonia transformatif. Berikut adalah cara baru bergereja ${ }^{31}$.

Cara baru bergereja ini tidak melihat tradisi dan aliran gereja seseorang. Aktivis diakonia transformatif melihat bahwa visi dan misi seseorang dalam bergereja lebih penting dari segalanya. Visi misi ini membebaskan orang miskin dan penuh perjuangan untuk membentuk dunia baru. Cara baru bergereja adalah kepedulian yang sama atas penderitaan rakyat. Membangun dan mengembangkan komunitas akar rumput sebagai cara baru bergereja. Mewujud dalam komunitas rakyat antar iman, lingkungan hidup, peduli pada buruh migran dan petani. Dengan satu visi membangun masa depan yang lebih adil. Selain itu, memahami sakramen dengan cara baru. Dalam diakonia transformatif, sakramen baik itu baptis atau ekaristi dipahami sebagai perjanjian antara Allah dan umatNya dalam Yesus. Durasingh teolog India mengatakan "perjanjian sebagai paradigma subversif untuk berbagi kehidupan dalam komunitas" ${ } 32$.

Sakramen dalam hal ini sebagai tanda subversif dan pembangkangan terhadap tatanan dunia yang penuh keserakahan dan dominasi yang kuat kepada yang lemah. Sakramen Baptis merupakan penolakan atas kedaulatan kaisar atau penguasa atas kehidupan yang tidak adil. Sakramen Perjamuan Kudus adalah simbol pesta pembagian roti untuk semua orang tanpa diskriminasi dan kelas. Semua orang dalam Perjamuan Kudus menerima roti dan anggur yang sama, tidak peduli siapapun orangnya. Ekonomi berbagi diberlakukan. Terakhir adalah cara baru dalam menjalankan misi. Misi dalam menjalankan diakonia transformatif menjadi misi bagi setiap orang yang belum

\footnotetext{
${ }^{30}$ Ibid., 105.

31 Ibid., 109.

32 Ibid., 111.
} 
memperoleh kembali kemanusiaannya sebagai gambar Allah karena ketidakadilan dan dosa sosial. Melalui diakonia transformatif gambar dan citra Allah yang rusak karena dosa asal dan dosa sosial dipulihkan kembali dengan memberdayakan manusia untuk menjadi subjek sejarah ${ }^{33}$.

\section{Diakonia Transformatif}

Diakonia merupakan tanda solidaritas yang dihubungkan dengan pendampingan, pemberdayaan, penyadaran atas hak-hak bagi yang lemah, miskin, dan tertindas. Konsep diakonia telah mengalami perkembangan. Ada tiga konsep yang dikenal dalam diakonia. Pertama, diakonia karitatif. Kedua, diakonia reformatif. Ketiga, diakonia transformatif. Ketiga bentuk diakonia ini, tidak bisa dihilangkan atau terabaikan. Sebab, masing-masing bentuk diakonia ini memberi perhatian dan kepedulian kepada masyarakat yang miskin, tertindas. Tujuan diakonia transformatif adalah terjadinya perubahan total dalam fungsi dan penampilan dalam kehidupan bermasyarakat. Membebaskan rakyat kecil, lemah, miskin, tertindas dari belenggu struktural yang tidak adil dan membelenggu mereka. Diakonia ini bisa dikatakan diakonia secara struktural transformatif.

Dalam pemahaman Abineno, diakonia transformatif disebut sosial-politis dan bagi Yosef, diakonia transformatif adalah pemberdayaan masyarakat miskin tertindas ${ }^{34}$. Rakyat diberdayakan dan disadarkan atas hak-haknya. Metode yang digunakan dalam diakonia transformatif adalah Organizing and empowering people. Pengorganisasian dan pemberdayaan diakonia transformatif berfokus pada: a. Rakyat sebagai subjek sejarah; $b$. Tidak karitatif, tetapi preventif; c. Tidak didorong oleh belaskasihan, tetapi keadilan; d. Mendorong partisipasi rakyat; e. Memakai alat analisis sosial dalam memahami sebabsebab kemiskinan; f. Melakukan penyadaran pada rakyat; g. Mengorganisasi rakyat. Pengorganisasian ini disebut community organization dengan tujuan untuk mengorganisasi rakyat dan memperoleh kekuatan untuk menegakkan keadilan ${ }^{35}$. Hal ini diakui oleh Asian Ecumenical Conference bahwa hanya rakyat yang mampu mengorganisasi diri mereka untuk keadilan sosial, maka orang tertindas dapat memperoleh kembali martabat mereka dan menolong menegakkan keadilan dan martabat bagi semua ${ }^{36}$. Dengan kata lain, keadilan hanya terjadi dengan perjuangan dari bawah, mereka yang diperlakukan tidak

\footnotetext{
${ }^{33}$ Ibid., 14.

${ }^{34}$ Mojau, Meniadakan Atau Merangkul? Pergulatan Teologis Protestan Dengan Islam Politik Di Indonesia, 120.

35 Ibid., 45.

${ }^{36}$ Ibid., 46.
} 
adil. Disinilah diakonia gereja hadir untuk mendampingi dan berinkarnasi atau menyatukan diri dengan mereka yang sedang berjuang untuk mewujudkan keadilan dan keselamatan. Seperti perjuangan atas kasus penggusuran tanah petani di Kedungombo, Boyolali, Jawa Tengah. Metode ini telah dikembangkan dan dijalankan oleh YBKS (Yayasan Bimbingan Kesejahteraan Sosial) Surakarta ${ }^{37}$.

Dalam menjalankan diakonia transformatif sangat penting partisipasi rakyat untuk menghadirkan keadilan. Ada beberapa alasan pentingnya partisipasi rakyat, antara lain adalah: a. Proyek akan mendarat dan dapat diterima oleh rakyat; b. Rakyat dengan sukarela akan memberikan sumbangan tenaga dan material karena mereka akan merasakan manfaat langsung dari proyek; c. Rakyat akan terbuka pada perubahan serta terlatih dalam mengelola proyek; d. Rakyat akan bertanggungjawab memelihara dan mengamankan proyek karena merasa ikut memiliki; e. Pengawasan proyek akan lebih efesien dan efektif. Partisipasi ini harus dimulai dari bawah bersama rakyat, mulai dari perencanaan, pelaksanaan, dan pengawasan ${ }^{38}$. Partisipasi rakyat ini dipahami sebagai jalan adanya pembagian kekuasaan. Sebagaimana yang disampaikan oleh Dewan Gereja se-Dunia pada tahun 1970 (WCC) bahwa dengan adanya partisipasi rakyat maka ada distribution, sharing of power in the decision making process ${ }^{39}$.

\section{Perbedaan dan Persamaan Teori Keadilan Rawls dan Diakonia Transformatif Josef}

Paham atau konsep kedua tokoh yaitu Rawls dan Josef memiliki perbedaan dan kesamaan dalam tujuan, yaitu untuk menghadirkan suatu tatanan masyarakat baru, berkeadilan, setara, hak dan kewajiban dilindungi dan diperhatikan oleh lembaga-lembaga serta masyarakat. Dibawah ini secara singkat menguraikan hal ini.

Ada beberapa hal yang menjadi perbedaan teori keadilan Rawls dan diakonia transformatif Josef antara lain: Pertama, subyek keadilan. Bagi Rawls, subyek utama keadilan adalah struktur dasar masyarakat. Rawls melihat bahwa dalam masyarakat sering terjadi ketimpangan, kesewenang-wenangan, masalah koordinasi, efisiensi, dan stabilitas di struktur dasar masyarakat ${ }^{40}$. Dari itu, struktur dasar masyarakat sangat penting untuk menjamin hak dan kewajiban fair. Sedangkan, Josef. Subyek utama keadilan adalah rakyat. Dalam menegakkan keadilan, rakyat yang menjadi subyek dan berperan aktif dalam

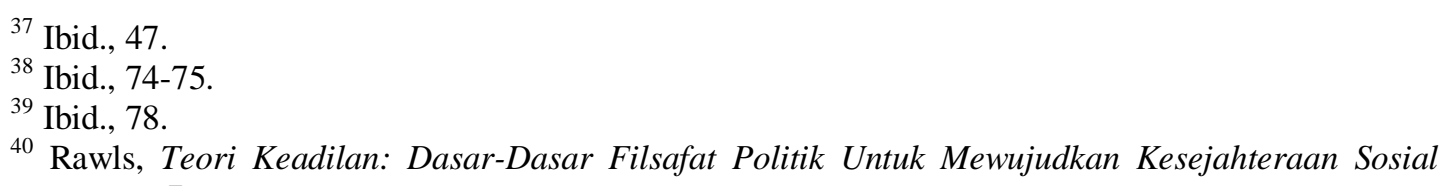
Dalam Negara, 6-7. 
perencanaan, pelaksanaan dan pengawasan dalam penegakkan keadilan ${ }^{41}$. Kedua, Rawls telah merumuskan dua prinsip keadilan yang menjadi dasar dan panduan utama dalam memutuskan dan mengambil kesepakatan di posisi asali ${ }^{42}$. Sedangkan, Josef lebih pada pengorganisasian yang disebut dengan community organization dengan tujuan untuk mengorganisasi rakyat yang didampingi fasilitator guna memperoleh kekuatan dan solusi menegakkan keadilan ${ }^{43}$. Ketiga, Rawls mendasari konsep teori keadilannya dengan keadilan sebagai fairness. Dengan menempatkan orang-orang tertentu untuk mengambil keputusan dan kesepakatan dalam menegakkan keadilan, yang disebut posisi asali (pihakpihak yang rasional, bebas, dan setara ${ }^{44}$. Sedangkan, Josef mendasari penegakkan keadilan dengan konsep misi Allah, misi yang membebaskan, dan menghadirkan atau menyatakan tanda-tanda Kerajaan Allah di dunia melalui diakonia transformatif. Josef mengatakan bahwa hanya dengan menyatukan diri (berinkarnasi) dengan mereka yang lemah, miskin, tertindas, tercipta gerakan perjuangan keadilan ${ }^{45}$. Oleh karena itu, melalui diakonia transformatif, dapat mengorganisasi komunitas yaitu rakyat itu sendiri, dan didampingi oleh organisator ${ }^{46}$ supaya membangkitkan rakyat dari kelumpuhan dan ketidakmampuan untuk mengubah realitas yang tidak adil menuju keadilan.

Persamaan dari teori keadilan Rawls dan diakonia transformatif Josef terletak pada penegakkan keadilan. Kedua tokoh ini, sangat serius dan fokus pada permasalahan ketidakadilan, sehingga mereka menggumuli dan mengusahakan supaya keadilan bisa ditegakkan di masyarakat, hak dan keawjiban diperhatikan dalam masyarakat. Ketimpangan, kesewenang-wenangan, sikap tidak bertanggungjawab sangat ditolak dan ditentang kedua tokoh ini. Harapan mereka adalah keadilan bisa terwujud bagi masyarakat.

\section{Kolaborasi Teori Keadilan Rawls dan Diakonia Transformatif Josef}

Dari uraian yang sudah dijelaskan, penulis mengkolaborasikan kedua teori ini dengan harapan menjadi alternatif atau panduan dalam memperjuangkan keadilan.

\footnotetext{
${ }^{41}$ Widyatmadja, Yesus Dan Wong Cilik: Praksis Diakonia Transformatif Dan Teologi Rakyat Di Indonesia, 102.

${ }^{42}$ Rawls, Teori Keadilan: Dasar-Dasar Filsafat Politik Untuk Mewujudkan Kesejahteraan Sosial Dalam Negara, 98.

${ }^{43}$ Widyatmadja, Yesus Dan Wong Cilik: Praksis Diakonia Transformatif Dan Teologi Rakyat Di Indonesia, 45.

${ }^{44}$ Rawls, Teori Keadilan: Dasar-Dasar Filsafat Politik Untuk Mewujudkan Kesejahteraan Sosial Dalam Negara, 20.

45 Widyatmadja, Yesus Dan Wong Cilik: Praksis Diakonia Transformatif Dan Teologi Rakyat Di Indonesia, 46.

${ }^{46}$ Rawls, Teori Keadilan: Dasar-Dasar Filsafat Politik Untuk Mewujudkan Kesejahteraan Sosial Dalam Negara, 50.
} 
Komunitas Akar Rumput: Suatu Alternatif

Berbicara tentang komunitas berarti berbicara tentang kelompok atau kumpulan yang lebih dari satu orang yang memiliki tujuan yang sama. Kamus besar bahasa Indonesia mengartikan komunitas adalah kelompok organisme (orang dan sebagainya) yang hidup dan saling berinteraksi di dalam daerah tertentu; masyarakat; paguyuban ${ }^{47}$. Dalam komunitas ada kekuatan yang menyatukan visi, kehendak, untuk kepentingan bersama, kebutuhan bersama atau ekonomi, politik, dan sosial. Biasanya komunitas bisa didasarkan atas kesamaan latar belakang budaya, ideologi, sosial-ekonomi. Penulis menyebut komunitas akar rumput, karena akar rumput merupakan sebuah sebutan pada kumpulan atau kelompok yang berada dibarisan paling dasar, yang sedang mengalami, merasakan ketidakadilan dan berjuang untuk keadilan. Kata Josef, rumput adalah sebagai simbol kekuatan rakyat yang sering dianggap lemah. Namun, memiliki daya mampu bertahan dalam situasi dan keadaan apapun ${ }^{48}$. Dalam kesemena-menaan terhadap ketidakadilan, akar rumput ini lebih menampakkan sikap tahan uji. Gambaran ini adalah gambaran wong cilik yang tidak pernah akan dibendung oleh keserakahan dan kesemena-menaan dari penguasa. Seperti apa yang dipahami oleh sosialisme dari bawah "...sosialisme hanya bisa diwujudkan melalui swa-pembebasan massa rakyat yang telah menjadi aktif bergerak, yang meraih kebebasannya dengan tangan mereka sendiri yang bermobilisasi 'dari bawah' dalam suatu perjuangan untuk mengambil tanggungjawab atas nasib mereka sendiri, sebagai aktor-aktor ... di atas panggung sejarah ${ }^{49}$. Maksud dari ini adalah supaya ada keseimbangan yang tercipta dalam membagi atau menentukan keuntungan yang fair. Selain itu, dalam komunitas akar rumput ada solidaritas dan partisipasi yang saling memikul beban satu sama lain, menjadi satu tubuh perjuangan, dan menjadi satu komunitas utuh. Oleh karena itu, keadilan, dan hadirnya masyarakat baru, dilakukan oleh komunitas tertindas itu sendiri, di mana mereka mengorganisir diri, menyadari ketertindasan, tahu sebab-musabab ketidakadilan, dan menemukan solusi serta jalan keluar, dengan percaya memobilisasikan diri untuk mengakhiri penindasan dan mewujudkan masyarakat dan dunia baru yang lebih fair.

\footnotetext{
47 Kamus Besar Bahasa Indonesia, "Komunitas," accessed January 15, 2019, https://kbbi.web.id/komunitas.

${ }^{48}$ Widyatmadja, Yesus Dan Wong Cilik: Praksis Diakonia Transformatif Dan Teologi Rakyat Di Indonesia, $103 \& 127$.

${ }^{49}$ Josef P Widyatmadja, Altar Dan Latar (Jakarta: Grafika KreasIndo, 2018), 176.
} 
Rawls menyebut komunitas penegakkan keadilan adalah posisi asali, dan Josef menyebut diakonia masyarakat atau diakonia transformatif ${ }^{50}$. Posisi asali dan diakonia transformatif memiliki tujuan yang sama yaitu terciptanya keadilan sosial. Dalam posisi asali dan diakonia transformatif, sama-sama menaruh kepedulian pada titik permasalahan yang ada dan mencoba memecahkan masalah sosial yang ada dengan menggunakan analisa sosial, pengorganisasisan masyarakat, penyadaran, dan berefleksi dari keadaan yang dialami rakyat, dan menghasilkan kesepakatan bersama.

Kebebasan dan Toleransi Berkeyakinan

Salah satu yang terus menyita perhatian masyarakat sampai saat ini adalah kebebasan berkeyakinan. Tidak sedikit kasus yang terjadi, disebabkan karena masalah keyakinan. Pihak-pihak yang merasa dirinya mayoritas berkuasa dan mengambil tindakan semena-mena. Hal-hal seperti ini berujung pada tindakan-tindakan kekerasan, penutupan rumah ibadah, mendatangkan massa dan sebagainya. Dalam temuan Biro penelitian dan Komunikasi PGI mengindikasikan bahwa makin melebar kerenggangan sosial masyarakat, terutama dalam hubungan antar umat beragama. Gejala-gejala ini dapat dilihat melalui praktik-praktik penetapan perda syariah, aturan-aturan yang diterapkan dalam tingkat lokal yang mewajibkan pengucapan dua kalimat syahadat di sekolah negeri, makin seringnya kekerasan dan konflik yang mengatasnamakan agama, menguatnya radikalisme dan fundamentalisme agama-agama, praktik dakwah dan misi Kristenisasi maupun Islamisasi 'vulgar' maupun melalui intimidasi maupun persuasi ekonomi yang menitikberatkan pada penambahan kuantitas, maraknya kebijakan-kebijakan politik yang diskriminatif ${ }^{51}$. Yusak mengatakan konflik dan kekerasan antar agama sesungguhnya tidak akan pernah mungkin terjadi, karena secara logis agama-agama tidak mungkin melakukan konflik satu sama lain. Fakta yang terjadi sepanjang sejarah peradaban manusia adalah penganut agamalah yang terlibat dalam konflik, baik konflik penganut agama yang sama maupun konflik antar penganut agama tertentu dan penganut agama yang lain, dalam tradisi iman yang sama

50 Widyatmadja, Yesus Dan Wong Cilik: Praksis Diakonia Transformatif Dan Teologi Rakyat Di Indonesia, 117.

${ }^{51}$ Komisi Teologi PGI, Berteologi Dalam Konteks: Meretas Jalan Menuju Perdamaian, Keadilan, Dan Keutuhan Ciptaan, ed. Jan S Aritonang, Olvi Prihutami, and Siahaan Tonggaor (Oikumene, Persetia, GKI, 2012), 84-85. 
maupun berbeda. Agama pada dasarnya berkonsepkan damai tetapi agama dapat dibajak oleh penganutnya untuk menimbulkan dan menjadi sumber konflik dan kekerasan ${ }^{52}$.

Selain itu, masih ada sejumlah faktor penyebab terjadinya intoleransi dalam berkeyakinan antara lain menguat dan menyebarnya kelompok-kelompok intoleran, lemahnya kebijakan dan regulasi negara, tunduk atau lemahnya aparatur negara kepada kelompok intoleran ${ }^{53}$. Selain itu faktor kepentingan penguasa atau pemodal yang membungkusnya dalam balutan agama, sangat meresahkan masyarakat dan meneror tiap pribadi yang berbeda keyakinan. Terbangun sebuah tembok pemisah. Di satu sisi hak semakin kondusif, tetapi di sisi lain masih terdapat fakta bahwa pemenuhan hak atas kebebasan beragama dan berkeyakinan merupakan masalah rumit untuk diselesaikan ${ }^{54}$. Padahal setiap manusia diberi kebebasan oleh Tuhan untuk memilih agama dan kepercayaan masing-masing tanpa khawatir ada gangguan dari yang lain.

Manusia hidup bersama dengan segala ciptaan Tuhan di bumi ini, hidup dalam keberanekaragaman. Dunia ini adalah dunia yang pluralistis, dunia yang penuh warna, dunia yang berbeda keyakinan. Kebebasan berkeyakinan merupakan kebutuhan primer bagi setiap individu. Rawls, dalam teori keadilannya membahas tentang kebebasan berkeyakinan ini. Dalam prinsip pertama teori keadilan sebagai fairness mengatakan bahwa "setiap orang mempunyai hak yang sama atas kebebasan dasar yang paling luas, seluas kebebasan yang sama bagi semua orang.” Kebebasan berkeyakinan termasuk dalam prinsip kebebasan yang utama ini. Kebebasan ini memiliki cakupan yang luas, seluas kebebasan itu tidak menghadirkan diskriminasi atau ketidakseimbangan dalam kehidupan masyarakat ${ }^{55}$.

Kebebasan berkeyakinan ini, dapat direfleksikan dalam tatanan pemerintahan Allah, sebagaimana Josef mengawali refleksi teologisnya dalam konsep Kerajaan Allah ${ }^{56}$. Alkitab sesungguhnya sangat menghargai kebebasan beragama, di mana umat Allah menerima keberadaan agama-agama yang memiliki keyakinan berbeda dengan umat Israel. Bahkan umat Israel menyatu dalam kehidupan sehari-hari dalam keberanekaragaman

${ }^{52}$ Yusak B Setyawan, Perdamaian Dan Keadilan: Dalam Konteks Indonesia Yang Multikultural Dan Beragam Tradisi Iman, ed. Nancy Souisa, Steve Gaspersz, and Ratnawati Lesawengen (Jakarta: BPK Gunung Mulia, 2017), 4.

53 Moh. Nadlir, “Tahun 2017, Pelanggaran Kebebasan Beragama Terbanyak Di Jawa Barat,” last modified 2018, https://nasional.kompas.com/read/2018/01/15/18233341/tahun-2017-pelanggaran-kebebasanberagama-terbanyak-di-jawa-barat.

${ }^{54}$ Agnes Dwi, "Solidaritas Bagi Kebebasan Beragama," Ma'arif 5, no. 2 (2010).

55 Ibid.

56 Widyatmadja, Yesus Dan Wong Cilik: Praksis Diakonia Transformatif Dan Teologi Rakyat Di Indonesia, 11-18. 
budaya, keyakinan, suku, ras. Misalnya, Kejadian 1-11 Allah berinteraksi dalam janjinya kepada dunia; Abraham diterima dan diberkati oleh imam Melkisedek yang tidak mengenal Allah yang sama (Kejadian 14:18); Allah yang disembah Musa diyakini oleh imam Yitro (Keluaran 2:16; 18:1,13,14,17). Yesus terbuka bagi orang-orang bukan Yahudi. Misalnya, wanita Samaria (Matius 15:28). Yesus hadir bagi semua orang karena prinsip Kerajaan Allah yang terbuka bagi semua orang dan golongan ${ }^{57}$. Kita dapat melihat dalam Mazmur 47:9-10, bahwa Allah adalah Allah bangsa-bangsa. Allah menciptakan semua manusia menurut gambar dan rupa Allah. Yesus memesan agar mengasihi sesama, sama seperti diri sendiri (bnd. Matius 22:39). Ini merupakan rumusan dalam kehidupan manusia yang berkeyakinan. Allah tidak memihak kepada siapapun. Allah membuka diri dan mau menerima bagi siapapun yang mau masuk dalam Kerajaan Allah.

Oleh karena itu, paham Rawls dan Josef, perlu dilihat dari keterbukaan atau universalitasnya Allah kepada umat manusia. Hal ini, harus menjadi pegangan dalam mengatur keberlangsungan keyakinan yang berbeda. Mengakui keuniversalan Allah. Kebebasan yang setara yang dikemukakan Rawls, harus menjadi fondasi dalam membangun nilai-nilai teologis dan moral. Titik keberhasilan akan terciptanya kebebasan berkeyakinan adalah ketika sang berkepentingan baik dari penguasa, pemodal atau urusan politik tidak mencampuri atau menjadi pembonceng dibalik keyakinan atau keagamaan yang ada. Orang-orang yang ada dalam komunitas atau posisi asali memilih suatu konstitusi atau negara yang tidak memiliki kaitan dan kepentingan terhadap kebebasan berkeyakinan supaya rakyat benar-benar berdaulat atas keyakinan yang dipilihnya. Negara dalam hal ini tidak mengurusi dogma atau filosofi agama, tetapi mengatur setiap individu sebagai warga masyarakat untuk memperlengkapi diri dan mengikuti sesuai kepentingn moral dan spiritual dengn prinsip-prinsip yang disepakati ${ }^{58}$. Kebebasan berkeyakinan tidak bisa tidak harus ada dibawah pengawasan agar bisa terdeteksi terhadap adanya dugaandugaan yang merusak atau merongrong tatanan masyarakat yang berjalan fair $^{59}$.

Perlu diketahui bahwa toleransi memiliki batas untuk menoleransi keyakinankeyakinan tertentu, jika atau apabila keyakinan tersebut mendatangkan ancaman, mengganggu ketertiban atau meresahkan masyarakat. Jadi, kebebasan yang setara tidak diberlakukan kepada keyakinan tersebut. Andil dan peran negara atau konstitusi juga punya peran untuk mengambil alih, mengontrol dan menjamin segala kesepakatan yang

\footnotetext{
${ }^{57}$ Joseph A Grassi, Perwujudan Ekaristi (Yogyakarta: Kanisius, 1989), 31.

${ }^{58}$ Rawls, Teori Keadilan: Dasar-Dasar Filsafat Politik Untuk Mewujudkan Kesejahteraan Sosial Dalam Negara, 267.

${ }^{59}$ Ibid., 268.
} 
telah diambil dalam posisi asali atau komunitas yang telah menyepakati prinsip-prinsip kesetaraan dalam berkeyakinan ${ }^{60}$. Yewangoe ${ }^{61}$ mengatakan kebebasan yang setara dalam berkeyakinan bisa berjalan dalam damai bila setiap individu tidak membangun tembok, dengan kata lain hidup dalam ghetto $^{62}$. Keberadaan di tengah-tengah keberanekaragaman di manapun berada harus hadir sebagai garam dan terang yang menciptakan suasana penuh cinta kasih, kepedulian dan keprihatinan antar masyarakat di sekitar. Dengan kata lain warga membangun solidaritas dan partispasi. Agama atau keyakinan seharusnya mendukung dan memberdayakan anggota-anggota komunitasnya untuk terlibat aktif dalam percaturan politik, dialog iman, saling memberi, membangun, menerima, dan saling menjunjung tinggi prinsip-prinsip keadilan ${ }^{63}$.

Dalam hal ini, masyarakat melihat dan mengamati hal-hal yang perlu dilakukan untuk membangun nilai-nilai kemanusiaan, menemukan titik singgung yang dapat bersama-sama menyelesaikan dan mengatasinya. Misalnya, masalah penderitaan hidup, kesusahan air bersih, gotong royong untuk kebersihan lingkungan atau kelurahan, menemukan kreasi dan inovasi bersama dan sebagainya. Hal ini senada dengan yang dikatakan Abdurrahman Wahid, yang dikutip oleh Yewangoe. Wahid mengatakan bahwa perlu upaya untuk mendudukkan agama-agama pada suatu tatanan baru. Bersama-sama membangun umat yang bersatu, membangun masyarakat yang adil dan makmur. Artinya, harkat dan martabat manusia merupakan keprihatinan mereka yang mendasar dan mendalam. Abdurrahman Wahid secara konkrit mengusulkan agar agama memberikan pelayanan kepada warga masyarakat tanpa pandang bulu dalam bentuk yang paling nyata, misalnya penanggulangan ekonomi, kemiskinan, kedaulatan hukum dan kebebasan menyatakan pendapat ${ }^{64}$. Apa yang dikatakan Abdurrahman Wahid ini, melihat bahwa kepelbagaian yang ada, seharusnya menjadi sumber kekayaan yang nyata. Sehingga apa yang dicita-citakan dunia baru, dan masyarakat yang berkeadilan terwujud.

${ }^{60}$ Ibid., 278.

61 A.A Yewangoe, Tidak Ada Ghetto, Gereja Di Dalam Dunia (Jakarta: Biro Penelitian dan Komunikasi PGI dan BPK Gunung Mulia, 2009), 36.

${ }^{62}$ Ibid., vii-viii. Kata ghetto bisa juga di tulis dengan getto, berasal dari bahasa Italia. Di dalam bahasa Ibrani, istilah yang di pakai adalah giudecca yang secara harafiah berarti "tembok Yahudi". Kata ini dipakai oleh Yewangoe karena mengacu pada kecenderungan Gereja yang lebih senang menarik diri "ke dalam" dengan alasan keamanan, ketimbang masuk ke dalam dunia nyata. Itu tidak berarti bahwa ada kesenangan di dalam ghetto. Namun, ketidakmampuan Gereja menghadapi dunia nyata membuat ia merasa lebih senang berada di dalam ghetto. Yewangoe mengatakan bahwa kalau Gereja sungguh-sungguh hendak menjadi Gereja Yesus Kristus yang concern dengan dunia, tidaklah pantas ia masuk ke dalam ghetto. Sebaliknya, ia harus berada di tengah-tengah dunia apa pun resikonya, menyataka diri sebagai bagian dari dunia, kendati tidak berasal dari dunia.

${ }^{63}$ Komisi Teologi PGI, Berteologi Dalam Konteks: Meretas Jalan Menuju Perdamaian, Keadilan, Dan Keutuhan Ciptaan, 114.

${ }^{64}$ Yewangoe, Tidak Ada Ghetto, Gereja Di Dalam Dunia, 11. 
Ekonomi yang Berkeadilan

Ekonomi berbicara tentang hajat hidup orang banyak. Ekonomi yang dikelola dengan buruk mendatangkan ketidakadilan dan kemiskinan bagi rakyat. Distribusi dan harga menjadi rancu dan dikendalikan oleh segelintir orang yang hanya memuaskan pribadi dan mengorbankan sesama. Apakah pertumbuhan ekonomi berdampak positif bagi rakyat? O, tidak. Orang miskin semakin miskin dan orang kaya semakin kaya. Inilah ketimpangan dan kesenjangan yang terjadi dalam pertumbuhan ekonomi. Ada sekat-sekat dan struktur yang menjadikan rakyat merasakan ketidakadilan. Untuk itu, Josef mengatakan bahwa tujuan dari diakonia transformatif adalah membebaskan rakyat kecil dari belenggu struktural yang tidak adil ${ }^{65}$. Permasalahan yang terjadi bukan terletak kepada pribadi pengusaha atau pelaku ekonomi. Pokok permasalahannya adalah menyangkut pada sistem produksi, distribusi dan konsumsi komoditas. Modus produksi yang tidak demokratis akan menaruh kekuasaan pada segelintir orang dan pihak yang lain adalah pihak yang dikuasai. Ini adalah bentuk penolakan terhadap Kerajaan Allah, tidak sekadar dilakukan secara individual, tetapi oleh suatu sistem yang diberlakukan dalam hubungan manusia terhadap roti atau produk pangan sebagai sumber kehidupan. Enrique Dussel teolog dari Meksiko ${ }^{66}$ memberikan gambaran tentang hubungan penindas dan yang ditindas dalam bentuk perampasan roti sebagai sumber kehidupan. Manusia tertindas adalah kaum miskin yang harus bekerja keras untuk menghasilkan roti dalam sebuah sistem atau struktur masyarakat. Dalam sistem ini tidak memungkinkan orang miskin mendapat roti yang dihasilkan oleh tangan mereka, tetapi roti tersebut diambil atau direbut oleh orang kaya. Setelah ditangan orang kaya, baru setelah itu sebagian kecil dibagikan kepada orang miskin melalui perbuatan amal mereka. Bagian yang besar dimiliki oleh mereka. Orang kaya hidup dalam keserakahan dengan mengambil banyak roti atau hasil pangan dan hanya sedikit dibagikan bagi orang miskin. Manusia penindas telah merampas martabat dan kemerdekaan atau kebebasan orang miskin.

Apa yang harus dilakukan dalam perjuangan ekonomi berkeadilan? Yahya Wijaya mengutip pandangan Calvin terhadap ekonomi. Dengan mengatakan bahwa bisnis merupakan bagian dari panggilan Ilahi, tetapi rawan oleh pencemaran oleh dosa. Itu sebabnya bisnis, sama seperti bidang-bidang lain, harus terus menerus di kawal dengan hukum Allah. Calvin tidak percaya bahwa pasar lepas dari dosa, pasar tidak dapat

${ }^{65}$ Widyatmadja, Yesus Dan Wong Cilik: Praksis Diakonia Transformatif Dan Teologi Rakyat Di Indonesia, 44.

66 Ibid., 66. 
mengatur dirinya sendiri. Maka, untuk mencapai ekonomi yang adil dan memulihkan solidaritas manusia, pasar jelas diregulasi ${ }^{67}$. Dalam Alkitab, Allah memberikan hukumhukum pasar, seperti hukum-hukum pertanahan, hewan ternak, buruh dan majikan, budak dan tuan, jual-beli, utang-piutang, mengelola keuangan dan sebagainya. Allah memberikan mandat kepada manusia sebagai wakil-Nya, bertanggung jawab untuk mengelola dan memelihara alam demi kemuliaan Allah, demi kebaikan manusia dan keutuhan ciptaan (Kejadian 1:28; 2:15). Kita dapat membaca dalam Imamat 25, Ulangan 15, Ulangan 25 tentang perhatian Allah yang sedemikian, menata aspek ekonomi supaya umat Allah boleh mencerminkan tatanan ekonomi yang berkeadilan, memperlakukan sesama, buruh, lembaga ekonomi, tanah, harta milik, hari kerja dan hari istirahat, hutang piutang dengan baik atau fair $^{68}$. Yesus dalam pelayanan-Nya selalu memberikan keutamaan bagi mereka yang tersisih miskin tertindas. Itu sebabnya Yesus mengajak seorang muda untuk melepas dan menjual segala kepunyaannya atau miliknya dan dibagi-bagikan kepada orang miskin.

Yesus memberikan makan lima ribu orang, yang menyatakan dan menyadarkan kita akan utamanya hidup yang tidak egois pada dirinya sendiri tetapi mau berbagi dalam keadaan apapun dan situasi apapun. Sakramen baptis dan ekaristi mengajarkan hidup berbagi di masyarakat, di mana sakramen gambaran keadilan, perbedaan kelas dan kekayaan tidak ada. Inilah gambaran masa depan di mana penindasan dan kemiskinan tidak ada. Rencana Allah memungkinkan ekonomi manusia tidak menjadi perhambaan materi, pemberhalaan harta benda, perbudakan keserakahan, melainkan merdeka penuh syukur, kesemarakan yang saling menumbuhkan dan yang menyukakan hati Allah. Kisah Para Rasul 2:44-45, mencatat cara hidup jemaat mula-mula, di mana ekonomi yang mereka terapkan adalah ekonomi yang diwarnai oleh makna sakramen dan panggilan hidup dalam Kerajaan Allah ${ }^{69}$.

Dalam pemahaman Rawls, ekonomi berkeadilan, harus ada dalam rumusan prinsipprinsip keadilan yang di tentukan dan disepakati oleh orang-orang yang ada dalam posisi asali. Rumusan prinsip yang dikemukakan Rawls adalah setiap orang berhak memperoleh hak-hak yang sama terhadap kebebasan seluas mungkin yang sama keadaannya dengan kebebasan yang dinikmati oleh semua orang. Keadilan ekonomi berbicara adanya kesempatan yang sama bagi setiap individu sehingga merupakan hak dari setiap individu

\footnotetext{
${ }^{67}$ Wijaya Yahya, "Relevansi Etika Calvin Bagi Konteks Indonesia Abad 21 Sebuah Kontribusi Dalam Rangka Peringatan 500 Tahun Calvin," Gema Teologi 33, no. 1 (2009): 93-102.

${ }^{68}$ Paul Hidayat, Hidup Dalam Ritme Allah (Jakarta: Persekutuan Pembaca Alkitab, 2005), 107.

${ }^{69}$ Ibid.; Grassi, Perwujudan Ekaristi, 39-40; John Wijngaards, Yesus Sang Pembaharu (Yogyakarta: Kanisius, 1994), 60-62.
} 
untuk memenuhi kebutuhannya, baik kebutuhan materi, sosial, budaya maupun spiritual ${ }^{70}$. Untuk itu Rawls menulis, bahwa sebuah sistem ekonomi mengatur benda-benda apa yang diproduksi dan dengan cara apa, dan siapa yang menerimanya dan sebagai hasilnya untuk sumbangan apa, dan seberapa besar sebagian sumber daya sosial yang disediakan untuk menyelamatkan dan memperlengkapi kebaikan-kebaikan masyarakat. Idealnya, sistem ekonomi ini diatur dengan cara yang memenuhi dua prinsip keadilan ${ }^{71}$. Di sini pentingnya kehadiran atau keberadaan sebuah komunitas yang membangun partisipasi kolektif untuk menyepakati hal-hal apa yang dapat menjalankan sebuah praksis ekonomi berkeadilan. Ekonomi berasaskan "produksi dan distribusi untuk memenuhi kebutuhan manusia" (dan bukan untuk keuntungan). Dengan kata lain, membangun suatu masyarakat dari bawah, terorganisir dalam sebuah komunitas yang berperan aktif untuk mengatur, mengendalikan dan mengontrol sistem perekonomian ${ }^{72}$. Bila tatanan ekonomi dan pendistribusian telah diatur dalam prinsip yang fairness, pendistribusian dan sistem yang berlaku mendatangkan kesejahteraan.

Nir-Kekerasan dalam Gerakan Perjuangan Komunitas

Sebuah gerakan atau komunitas yang melakukan perjuangan atas ketidakadilan, selalu berbentur dengan pihak-pihak yang memiliki kepentingan, entah dari penguasa atau pemilik modal atau dari pihak pemerintah. Inkarnasi yang kita kenal di dalam Allah, bertindak dari tempat Mahatinggi turun ke dunia menjadi daging, tidak bisa di lepaskan dengan fenomena yang dialami, di mana berhadapan dengan konflik, dari Bethlehem sampai ke Golgota. Konflik tak terhindarkan dalam sebuah penegakan keadilan, ada pihak yang senantiasa bertahan dan melanggengkan keadaan yang menurut dia nyaman, mendatangkan keuntungan bagi diri sendiri dan mengorbankan pihak lain. Dalam suatu perjuangan, konflik tidak dapat terhindarkan. Maksudnya adalah bahwa dalam setiap perjuangan keadilan, berhadapan dengan kuasa-kuasa yang menjadi sumber konflik. Dengan kata lain, orang-orang yang berjuang demi keadilan selalu dianggap subversif. Dianggap subversif karena mengganggu keamanan dan stabilitas serta merupakan agen

${ }^{70}$ Komisi Teologi PGI, Berteologi Dalam Konteks: Meretas Jalan Menuju Perdamaian, Keadilan, Dan Keutuhan Ciptaan, 157.

${ }^{71}$ Rawls, Teori Keadilan: Dasar-Dasar Filsafat Politik Untuk Mewujudkan Kesejahteraan Sosial Dalam Negara, 343.

${ }^{72}$ Tissa Balasurya, Teologi Siarah (Jakarta: BPK Gunung Mulia, 1994), 277. 
komunis ${ }^{73}$. Padahal, orang-orang yang ditangkap berjuang untuk menyuarakan penderitaan rakyat, kebebasan martabat manusia, keadilan sosial, serta pengisapan oleh modal asing perusahaan multinasional.

Nabi-nabi yang diutus Allah, ditolak oleh para penguasa dan pemilik modal. Yesus datang ke dunia ditolak oleh penguasa dunia sampai berujung di kayu salib. Bagi penguasa dan yang punya kepentingan segala tindakan yang dilakukan oleh gerakan atau komunitas yang memperjuangkan keadilan selalu dianggap subversif. Bagaimana kita menyikapi dan membahas hal ini? Apakah tuduhan subversif harus dilawan dengan kekerasan? Rawls menyikapi ini dalam konsep pembangkangan sipil: keadaan dan kondisi secara obyektif masyarakat hampir menjadi masyarakat fair dalam tatanan baru. Pembangkangan sipil yang dikemukakan Rawls jauh dari namanya kekerasan. Berikut ini dapat dilihat bagaimana Rawls menempatkan konsep nir-kekerasan dalam paham pembangkangan sipil.

Pertama, pembangkangan sipil adalah sebuah tindakan politik. Ia berlangsung secara terbuka dengan peringatan yang cukup, tidak tertutup/ diam-diam, berlangsung pada forum publik. Kedua, pembangkangan sipil adalah nir-kekerasan. Ia berusaha menjauhi penggunaan kekerasan, utamanya terhadap perseorangan, bukan karena kebencian terhadap penggunaan paksaan pada dasarnya, melainkan karena itulah ekspresi final kasus seseorang. Ketiga, nir-kekerasan ditampilkan sebagai pembangkangan kepada hukum dalam batas-batas kesetiaan pada hukum. Hukum dilanggar, tetapi kesetiaan pada hukum diungkapkan oleh watak publik. Di sini, kita harus membayar harga tertentu guna meyakinkan orang lain bahwa aksi kita memiliki dalam pandangan yang di pertimbangkan masak-masak, sebuah basis moral yang memadai dalam keyakinan politik komunitas ${ }^{74}$. Rawls mengikuti jalan atau gerakan yang dilakukan Yesus dan Mahatma Gandhi dengan berjuang tanpa kekerasan. Nir-kekerasan yang diterapkan Rawls menjadi upaya tidak terjadinya korban yang berdarah-darah atau menghindari perjuangan dari terenggut nyawa manusia. Seperti Josef mengatakan bahwa rakyat memiliki kekuatan yang tahan uji, sama seperti rumput yang selalu bertahan dalam kondisi apapun.

Nir-kekerasan inilah yang menjadi salah satu kekuatan rakyat Kedungombo, Jawa Tengah, ketika menghadapi intimidasi, penganiayaan selama lima tahun lebih (1983-1988), mereka bertahan diri tanpa kekerasan sehingga tidak mudah bagi pemerintah untuk menuduhnya sebagai pengacau dan sebagainya. Nir-kekerasan yang mereka pilih adalah

${ }^{73}$ Widyatmadja, Yesus Dan Wong Cilik: Praksis Diakonia Transformatif Dan Teologi Rakyat Di Indonesia, 87.

${ }^{74}$ Rawls, Teori Keadilan: Dasar-Dasar Filsafat Politik Untuk Mewujudkan Kesejahteraan Sosial Dalam Negara, 472-474. 
suatu kekuatan rakyat yang tersembunyi datangnya dari Allah ${ }^{75}$. Nir-kekerasan harus diimbangi dengan spiritualitas pembebasan. Sebab, dalam spiritualitas pembebasan tidak ada sikap balas dendam, kemarahan, kekerasan. Seperti Paulus menghayati spiritualitas pembebasan dalam frasa "mati bersama Kristus", dan "disalibkan bersama Kristus". Bagi Paulus, pernyataan ini adalah bentuk perlawanannya tanpa kekerasan terhadap pemerintah Romawi, Paulus melawan praktik ketidakadilan yang dilakukan penguasa Romawi ${ }^{76}$. Termasuk ideologi imperialis yang dipropagandakannya. Inilah namanya perlawanan dalam bentuk resistensi. Rumput dihina, membisu, diinjak-injak, dibabat, dan diberi kotoran, tetapi semuanya menjadi alat untuk memperkuat dan mengokohkan akar rumput agar badai dan goncangan apapun tidak menghalangi dan menghentikan langkah perjuangan untuk tatanan baru, masyarakat yang berkeadilan ${ }^{77}$.

\section{Kesimpulan}

Berdasarkan pembahasan yang sudah diberikan dapat disimpulkan bahwa keadilan bisa ditegakkan. Kolaborasi teori keadilan Rawls dan diakonia transformatif Josef menjadi alternatif untuk memperjuangkan keadilan. Dari konsep yang telah diuraikan, setidaknya memberikan sumbangsih kepada komunitas dan masyarakat untuk memperjuangkan keadilan. Rawls dan Josef telah memberikan pemahaman atau konsep keadilan tentang bagaimana memperjuangkan keadilan. Rawls dengan konsep posisi asali dan Josef dengan konsep diakonia transformatif, meyakini bahwa untuk menyelesaikan dan memecahkan masalah sosial, harus dibicarakan atau dikomunikasikan bersama aktivis atau fasilitator yang berjuang untuk keadilan, memecahkan masalah dan mencari solusi serta mengambil kesepakatan bersama dengan berpegang pada dua prinsip keadilan Rawls. Pada intinya bahwa dalam kebersamaan, komunitas akan menghasilkan prinsip-prinsip keadilan dan menemukan solusi untuk menyelesaikan ketidakadilan. Dalam hal ini, keterlibatan semua pihak, kalangan, golongan mempengaruhi hasil yang didapatkan untuk penyelesaian setiap permasalahan ketidakadilan yang terjadi. Semoga keadilan ditegakkan bagi segenap masyarakat.

${ }^{75}$ Widyatmadja, Yesus Dan Wong Cilik: Praksis Diakonia Transformatif Dan Teologi Rakyat Di Indonesia, 125.

76 Demianus Nataniel, "Salib Kristus Sebagai Retorika Paulus Dalam Melawan Imperialisme Romawi” (STT Jakarta, 2017), 132.

77 Widyatmadja, Yesus Dan Wong Cilik: Praksis Diakonia Transformatif Dan Teologi Rakyat Di Indonesia, 132. 


\section{Kepustakaan}

Balasurya, Tissa. Teologi Siarah. Jakarta: BPK Gunung Mulia, 1994.

Dwi, Agnes. "Solidaritas Bagi Kebebasan Beragama." Ma'arif 5, no. 2 (2010).

Grassi, Joseph A. Perwujudan Ekaristi. Yogyakarta: Kanisius, 1989.

Hidayat, Paul. Hidup Dalam Ritme Allah. Jakarta: Persekutuan Pembaca Alkitab, 2005.

Indonesia, Kamus Besar Bahasa. "Komunitas.” Accessed January 15, 2019. https://kbbi.web.id/komunitas.

Komisi Teologi PGI. Berteologi Dalam Konteks: Meretas Jalan Menuju Perdamaian, Keadilan, Dan Keutuhan Ciptaan. Edited by Jan S Aritonang, Olvi Prihutami, and Siahaan Tonggaor. Oikumene, Persetia, GKI, 2012.

Mojau, Julianus. Meniadakan Atau Merangkul? Pergulatan Teologis Protestan Dengan Islam Politik Di Indonesia. Jakarta: BPK Gunung Mulia, 2012.

Nadlir, Moh. "Tahun 2017, Pelanggaran Kebebasan Beragama Terbanyak Di Jawa Barat." Last modified 2018. https://nasional.kompas.com/read/2018/01/15/18233341/tahun2017-pelanggaran-kebebasan-beragama-terbanyak-di-jawa-barat.

Nataniel, Demianus. “Salib Kristus Sebagai Retorika Paulus Dalam Melawan Imperialisme Romawi.” STT Jakarta, 2017.

Rasuanto, Bur. Keadilan Sosial: Pandangan Deontologis Rawls Dan Habermas, Dua Teori Filsafat Politik Modern. Jakarta: Gramedia, 2005.

Rawls, John. Teori Keadilan: Dasar-Dasar Filsafat Politik Untuk Mewujudkan Kesejahteraan Sosial Dalam Negara. Yogyakarta: Pustaka Pelajar, 2006.

Setyawan, Yusak B. Perdamaian Dan Keadilan: Dalam Konteks Indonesia Yang Multikultural Dan Beragam Tradisi Iman. Edited by Nancy Souisa, Steve Gaspersz, and Ratnawati Lesawengen. Jakarta: BPK Gunung Mulia, 2017.

Ujan, Andre Ata. Keadilan Dan Demokrasi: Telaah Filsafat Politik John Rawls. Yogyakarta: Kanisius, 2005.

Widyatmadja, Josef P. Altar Dan Latar. Jakarta: Grafika KreasIndo, 2018.

—. Yesus Dan Wong Cilik: Praksis Diakonia Transformatif Dan Teologi Rakyat Di Indonesia. Jakarta: BPK Gunung Mulia, 2010.

Wijngaards, John. Yesus Sang Pembaharu. Yogyakarta: Kanisius, 1994.

Yahya, Wijaya. "Relevansi Etika Calvin Bagi Konteks Indonesia Abad 21 Sebuah Kontribusi Dalam Rangka Peringatan 500 Tahun Calvin.” Gema Teologi 33, no. 1 (2009): 93-102.

Yewangoe, A.A. Tidak Ada Ghetto, Gereja Di Dalam Dunia. Jakarta: Biro Penelitian dan Komunikasi PGI dan BPK Gunung Mulia, 2009. 